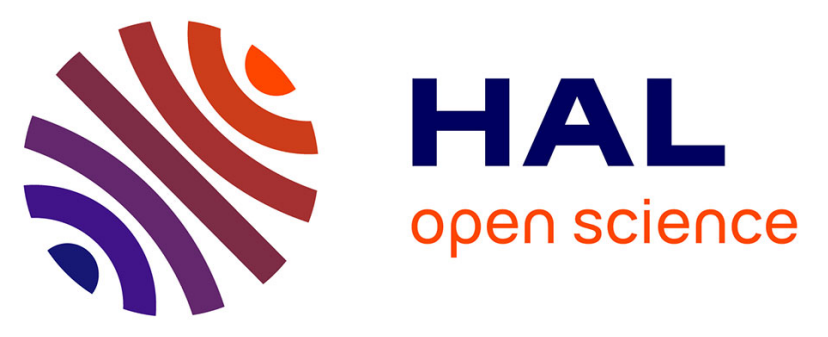

\title{
Alkoxyallene-ynes: Selective Preparation of Bicyclo[5.3.0] Ring Systems Including a $\delta$-Alkoxy Cyclopentadienone
}

Aurélien Tap, Camille Lecourt, Sabrina Dhambri, Mathieu Arnould, Gilles Galvani, Olivier Nguyen van buu, Morgan Jouanneau, Jean-Pierre Férézou, Janick Ardisson, Marie-Isabelle Lannou, et al.

\section{To cite this version:}

Aurélien Tap, Camille Lecourt, Sabrina Dhambri, Mathieu Arnould, Gilles Galvani, et al.. Alkoxyallene-ynes: Selective Preparation of Bicyclo[5.3.0] Ring Systems Including a $\delta$ Alkoxy Cyclopentadienone. Chemistry - A European Journal, 2016, 22 (14), pp.4938-4944. 10.1002/chem.201504753 . hal-02370516

\section{HAL Id: hal-02370516 https://hal.science/hal-02370516}

Submitted on 14 Oct 2021

HAL is a multi-disciplinary open access archive for the deposit and dissemination of scientific research documents, whether they are published or not. The documents may come from teaching and research institutions in France or abroad, or from public or private research centers.
L'archive ouverte pluridisciplinaire HAL, est destinée au dépôt et à la diffusion de documents scientifiques de niveau recherche, publiés ou non, émanant des établissements d'enseignement et de recherche français ou étrangers, des laboratoires publics ou privés. 


\title{
Alkoxyallene-ynes: Selective Preparation of Bicyclo[5.3.0] Ring Systems Including a $\delta$-Alkoxy Cyclopentadienone
}

\author{
Aurélien Tap,${ }^{\text {[a] }}$ Camille Lecourt, ${ }^{\text {[a] }}$ Sabrina Dhambri, ${ }^{[a]}$ Mathieu Arnould, ${ }^{[a]}$ Gilles Galvani, ${ }^{[a]}$ \\ Olivier Nguyen Van Buu, ${ }^{[\mathrm{ac}]}$ Morgan Jouanneau, ${ }^{[\mathrm{b}]}$ Jean-Pierre Férézou, ${ }^{[\mathrm{b}]}$ Janick Ardisson, ${ }^{[\mathrm{a}]}$ \\ Marie-Isabelle Lannou, ${ }^{*[a]}$ and Geoffroy Sorin ${ }^{*[a]}$
}

Abstract: The development of an intramolecular rhodium(I)catalyzed Pauson-Khand reaction of alkoxyallene-ynes with a proximal alkoxy group is reported. This reaction, in the presence of a $[\mathrm{Rh} \text { (cycloocta-1,5-diene) } \mathrm{Cl}]_{2} /$ propane-1,3-diylbis(diphenylphosphane) system under a CO atmosphere, constitutes a powerful tool for selectively accessing carboand heterobicyclo[5.3.0] frameworks featuring an enol ether moiety. Through this procedure, a straightforward access to guaiane skeletons with a tertiary hydroxy group at the C10 position was achieved.

\section{Introduction}

Sesquiterpenes represent the largest class of terpenes and, among the variety of ring systems that are featured in these natural products, the guaianes, characterized by fused fiveand seven-membered rings (bicyclo[5.3.0]decane), are widespread. Although their core structures might differ in the oxidation level, many of them present a tertiary hydroxy group at the $\mathrm{C} 10$ position (guaiane numbering; Figure 1). ${ }^{[1]}$

Their total synthesis represents a real challenge including three key points: a medium ring, dense stereochemical complexity on a relatively flexible skeleton, and often highly elevated levels of oxidation. The intramolecular Pauson-Khand reaction (PKR), that is, an ene-yne or allene-yne carbonylative $[2+2+1]$ reaction, constitutes an efficient and elegant method for synthesizing perhydroazulene skeletons. ${ }^{[2]}$ Therefore, we hypothesized that the alkoxyallene-yne cyclocarbonylation reaction of substrates bearing an alkoxy group at the proximal position should permit the rapid elaboration of the carbon framework of guaianes possessing a tertiary alcohol group at the C10 position with the requisite unsaturation for further functionalization (guaiane numbering; Scheme 1)..$^{[3]}$

[a] Dr. A. Tap, C. Lecourt, S. Dhambri, M. Arnould, Dr. G. Galvani,

Dr. O. Nguyen Van Buu, Prof. J. Ardisson, Dr. M.-I. Lannou, Dr. G. Sorin

Faculté des Sciences Pharmaceutiques et Biologiques

Unité CNRS UMR 8638 COMĖTE

Paris Descartes University, Sorbonne Paris Cité

4 avenue de l'observatoire, 75270 Paris cedex 06 (France)

E-mail:marie-isabelle.lannou@parisdescartes.fr geoffroy.sorin@parisdescartes.fr

[b] Dr. M. Jouanneau, Dr. J.-P. Férézou

Laboratoire de Chimie des Procédés et Substances Naturelles

ICMMO (CNRS UMR 8182), Université Paris-Sud

Bâtiment 410, 91405 Orsay Cedex (France)

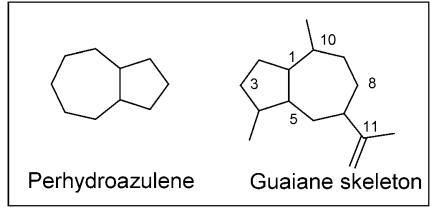

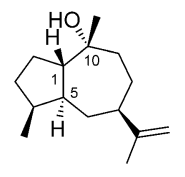

Pogostol
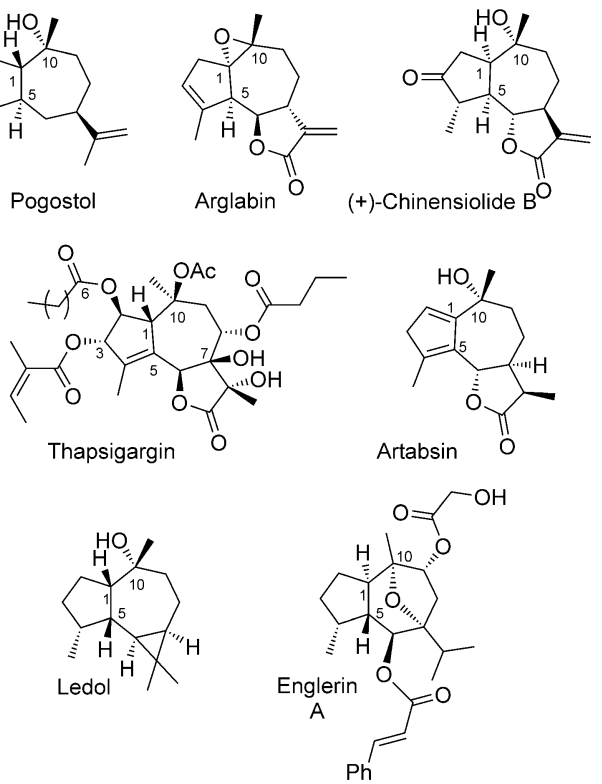

Figure 1. Natural products containing a guaiane skeleton with a tertiary hydroxy group at the $\mathrm{C} 10$ position.

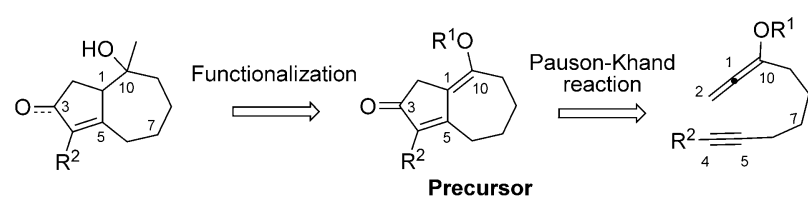

Scheme 1. Strategy for the synthesis of guaianes possessing a tertiary alcohol at the $\mathrm{C} 10$ position. 
In 1996, pioneering work performed by Pericas and co-workers already established that enol ether precursors can be used as olefinic partners with alkynes in the PKR. ${ }^{[4]}$ One year later, Cazes and co-workers reported an intermolecular cobalt-mediated PKR involving a tert-butoxyallene in the presence of a tertiary amine oxide as a promoter; however, the yields remained low (30\%). ${ }^{[5]}$ More recently, Pérez-Castells and co-workers studied the intramolecular PKR of aryloxyallene-ynes, promoted by a molybdenum complex. Nonetheless, the reaction suffered from a lack of selectivity, because both internal and external double bonds of the allene were prone to react. ${ }^{[6]}$ Finally, in 2009, Brummond et al. described the conversion of allenol acetates into bicyclo[5.3.0] skeletons containing an $\alpha$-acetoxy cyclopentadienone by means of $\mathrm{Rh}^{\prime}$-catalyzed cyclocarbonylation, which selectively occurs through the external $\pi$ bond of the allene. Notably, in this case, the allene is substituted by the alkoxy group at the distal position (Scheme 2). ${ }^{[7]}$
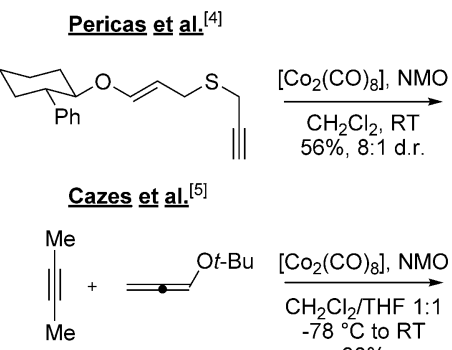

$30 \%$

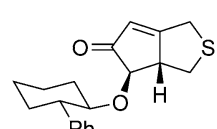

$\mathrm{Ph}$

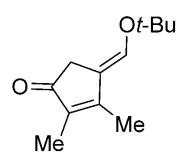

Pérez-Castells et al. ${ }^{[6]}$
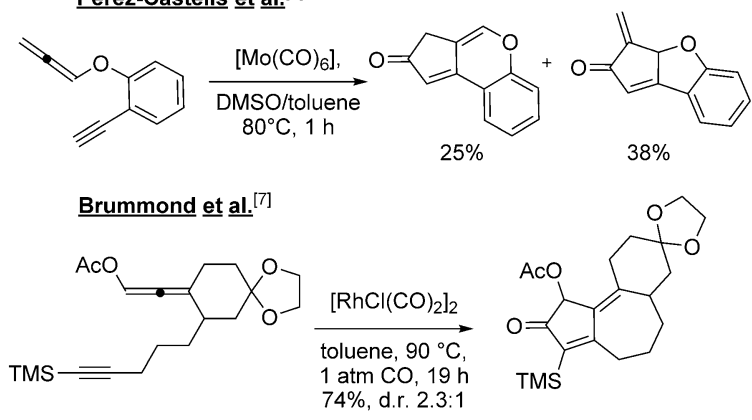

Scheme 2. PKRs with enol ethers or alkoxyallenes. NMO: 4-methylmorpholine $\mathrm{N}$-oxide; TMS: trimethylsilyl.

Although the intramolecular PKR of alkoxyallene-ynes with an alkoxy group at the proximal position appears to be an attractive way to access complex structures, the scarcity of reports in this field encouraged us to investigate the reaction. To this aim, a wide variety of cycloaddition substrates was prepared and submitted to PKR conditions to provide bicyclo[5.3.0] ring systems bearing an enol ether moiety, which constitutes a logical tertiary hydroxy group precursor. It is noteworthy that alkoxyallenes are highly versatile structures; thus, the success of this study will rely on the setting of sufficiently mild and chemoselective conditions, not only in the course of the key PKR but also during the elaboration of the alkoxyallene-yne precursors, in order to preserve the integrity of these skeletons. The results of this survey are reported herein.

\section{Results and Discussion}

Investigation into the scope of this intramolecular cyclocarbonylation reaction was initiated with the preparation of a range of readily accessible alkoxyallene-ynes. To this end, three different allene-alkyne linkages were envisioned: one all-carbon and two heteroatom-containing tethers (respectively, the carbon, nitrogen, and oxygen series). The other variations involved the substitution pattern of the alkoxyallene $\left(R^{1}\right)$ that features a benzyl (Bn), a para-methoxybenzyl (PMB), or a carbamate $\left(\mathrm{CON}(\mathrm{iPr})_{2} ; \mathrm{Cb}\right)$ group and the terminus of the alkyne $\left(\mathrm{R}^{2}\right)$ exhibiting either hydrogen, methyl, ethyl, $\mathrm{CH}_{2} \mathrm{OBn}$, or trimethylsilyl groups.

Our strategy to access the required alkoxyallene-yne precursors $\mathbf{3}$ involved the addition of lithiated alkoxyallenes $\mathbf{2}$ onto aldehydes 1 . The transformation of these compounds into the corresponding perhydroazulene systems $\mathbf{4}$ was then studied (Scheme 3).

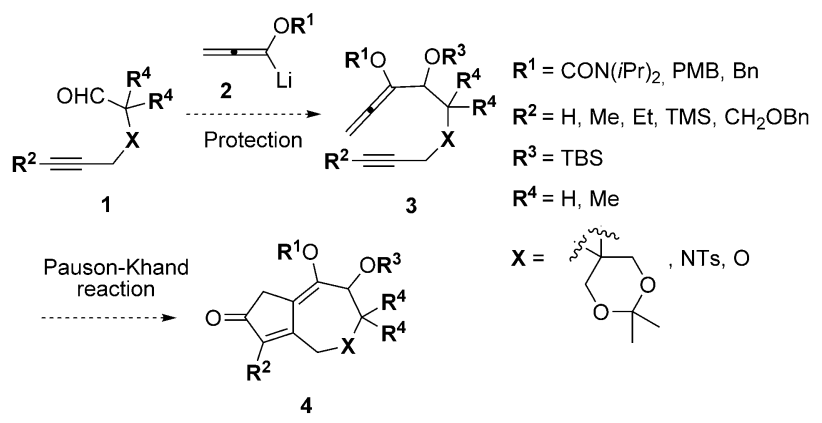

Scheme 3. Investigation into intramolecular PKRs of alkoxyallene-ynes with the alkoxy group at the proximal position. TBS: tert-butyldimethylsilyl; Ts: toluene-4-sulfonyl.

\section{Synthesis of alkoxyallenic Pauson-Khand precursors}

The starting point for the study consisted of the preparation of the oxygen-substituted allenes $6 \mathrm{a}(\mathrm{OCb}), 6 \mathrm{~b}(\mathrm{OBn})^{[8]}$ and $6 \mathrm{c}$ $(\mathrm{OPMB}){ }_{,}^{[9]}$ from propargyl carbamate $\mathbf{5} \mathrm{a}^{[10]}$ or propargyl ethers $\mathbf{5 b}$ and $\mathbf{5 c}$ by using a general procedure for base-promoted isomerization (Scheme 4). ${ }^{[11]}$

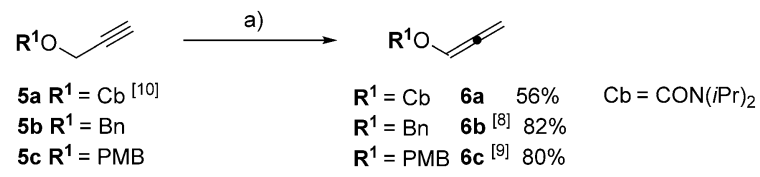

Scheme 4. Preparation of oxygen-substituted allenes. a) tBuOK ( 0.3 equiv), THF, RT, $1 \mathrm{~h}$.

The synthesis of the aldehydes in the carbon series, $8 \mathbf{a}\left(R^{2}\right.$ : $H)$, 8 b $\left(R^{2}: M e\right), 8 c\left(R^{2}: E t\right), 8 d\left(R^{2}: T M S\right)$, and 8 e $\left(R^{2}: \mathrm{CH}_{2} \mathrm{OBn}\right)$, was next performed from the corresponding alkenes $7 a^{[12]}$ $\mathbf{7} b_{1}^{[13]} \mathbf{7 c}, \mathbf{7 d}$, and $\mathbf{7 e}$ by oxidative cleavage with good yields. Alkene $7 \mathbf{d}\left(\mathrm{R}^{2}\right.$ : TMS) was prepared by silylation of terminal 
alkyne $7 \mathrm{a}$; alkenes $7 \mathrm{c}\left(\mathrm{R}^{2}\right.$ : Et) and 7 e $\left(\mathrm{R}^{2}: \mathrm{CH}_{2} \mathrm{OBn}\right)$ were obtained by following a two-step sequence: reduction of diesters $9 \mathrm{a}^{[14]}$ and $\mathbf{9 b}$ and subsequent protection. Finally, alkylation of allylmalonate $\mathbf{1 0}$ with mesylate $\mathbf{1 1}^{[15]}$ allowed the formation of diester $9 \mathbf{b}\left(\mathrm{R}^{2}\right.$ : $\mathrm{CH}_{2} \mathrm{OBn}$; Scheme 5).
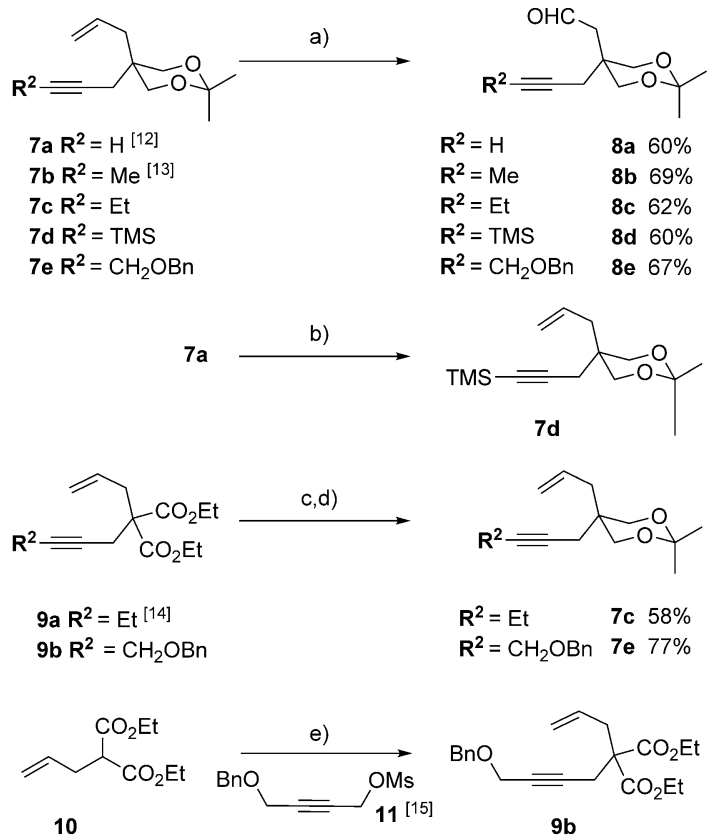

Scheme 5. Synthesis of aldehydes in the carbon series. a) $\mathrm{O}_{3}, \mathrm{CH}_{2} \mathrm{Cl}_{2},-78^{\circ} \mathrm{C}$ then $\mathrm{PPh}_{3}$. b) $n \mathrm{BuLi}, \mathrm{TMSCl}$, THF, quant. c) $\mathrm{LiAlH}_{4}, \mathrm{THF}, 0^{\circ} \mathrm{C}$ to RT, 1.5 h. d) 2,2dimethoxypropane, PPTS, $\mathrm{CH}_{2} \mathrm{Cl}_{2}, \mathrm{RT}, 16 \mathrm{~h}$. e) $\mathrm{NaH}, \mathrm{DMF}, 0^{\circ} \mathrm{C}, 15 \mathrm{~min}$, then $11,0{ }^{\circ} \mathrm{C}, 1 \mathrm{~h}, 91 \%$. Ms: methanesulfonyl; PPTS: pyridinium $p$-toluenesulfonate.

The synthesis of the required PKR precursors from aldehydes $\mathbf{8} \mathbf{a}-\mathbf{e}$ was then readily performed in two steps: reaction of lithiated alkoxyallenes, generated by selective gem-deprotonation of the corresponding oxygen-substituted allenes $6 \mathbf{a}-\mathbf{c}$, with aldehydes $\mathbf{8} \mathbf{a}-\mathbf{e}$ at low temperature and direct conversion of the resulting alcohols into the corresponding TBS ethers $12 \mathrm{a}-\mathrm{e}, 13 \mathrm{a}, 13 \mathrm{~b}$, and $14 \mathrm{a}-\mathrm{d}$ (Scheme 6). ${ }^{[16]}$

In the nitrogen series, alkoxyallene-ynes $16 \mathrm{a}-\mathrm{c}, 17 \mathrm{a}-\mathrm{c}$, and $18 \mathbf{a}-\mathbf{d}$ were similarly synthesized through coupling of lithiated alkoxyallenes derived from $6 \mathrm{a}-\mathrm{c}$ with aldehydes $15 \mathrm{a}\left(\mathrm{R}^{2}: \mathrm{H}\right){ }_{1}^{[17]}$ 15 b $\left(R^{2}: \mathrm{Et}\right),{ }^{[18]} 15 \mathrm{c}\left(\mathrm{R}^{2}: \mathrm{TMS}\right),{ }^{[19]}$ and $15 \mathrm{~d}\left(\mathrm{R}^{2}: \mathrm{CH}_{2} \mathrm{OBn}\right)$ and subsequent protection as TBS ethers (Scheme 7). Aldehyde $15 \mathbf{d}$ was prepared in two steps from propargylic alcohol 19. ${ }^{[20,21]}$

Finally, in the oxygen series, the PKR precursors $23 \mathbf{a}-\mathbf{b}$ and 24a-b were elaborated in a similar way from alkoxyallenes $6 \mathbf{a}$ and $\mathbf{6 c}$ and aldehyde 22. Aldehyde 22 was synthesized in a four-step sequence from known tertiary alcohol 20 $0^{[22]}$ via alkyne 21 (Scheme 8).

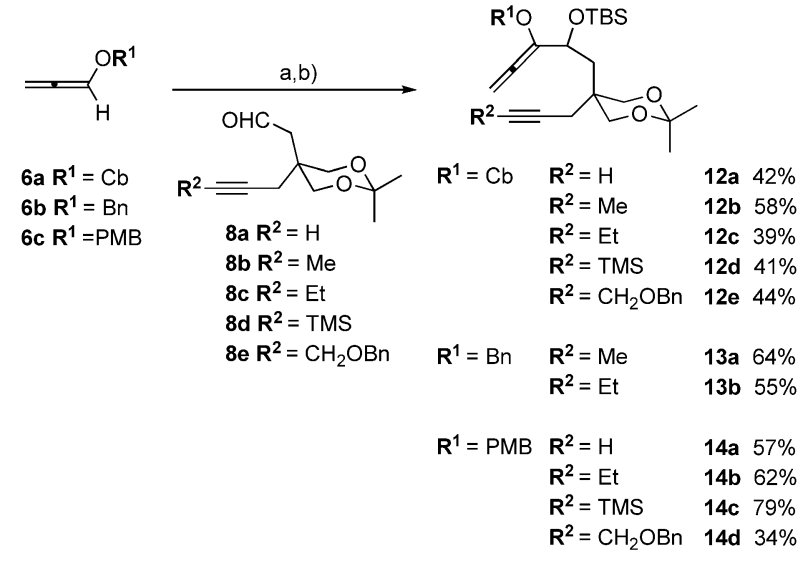

Scheme 6. Preparation of alkoxyallene-ynes in the carbon series. a) $n \mathrm{BuLi}$, THF, $-78^{\circ} \mathrm{C}, 30 \mathrm{~min}$, then $8 \mathrm{a}-\mathbf{e}, \mathrm{THF},-78^{\circ} \mathrm{C}, 30 \mathrm{~min}$. b) TBSOTf, 2,6-lutidine, $\mathrm{CH}_{2} \mathrm{Cl}_{2}, 0^{\circ} \mathrm{C}, 3 \mathrm{~h}$.

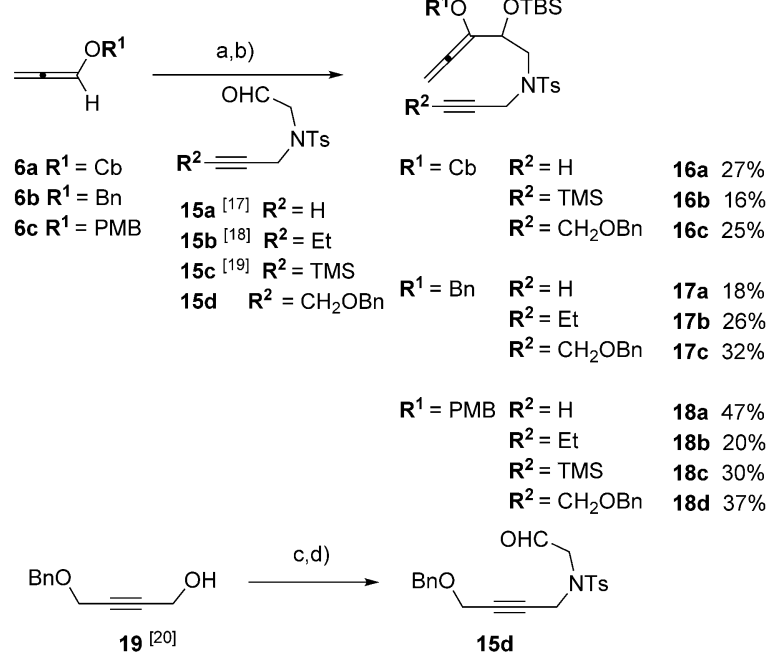

Scheme 7. Preparation of alkoxyallene-ynes in the nitrogen series. a) $n B u L i$ $\mathrm{THF},-78^{\circ} \mathrm{C}, 30 \mathrm{~min}$, then $15 \mathrm{a}-\mathrm{d}, \mathrm{THF},-78^{\circ} \mathrm{C}, 30 \mathrm{~min}$. b) TBSOTf, 2,6-lutidine, $\mathrm{CH}_{2} \mathrm{Cl}_{2}, \mathrm{O}^{\circ} \mathrm{C}, 3 \mathrm{~h}$. c) DIAD, $\mathrm{PPh}_{3}, \mathrm{~N}$-allyl-4-methyl-benzenesulfonamide, $71 \%$. d) $\mathrm{O}_{3}, \mathrm{CH}_{2} \mathrm{Cl}_{2},-78^{\circ} \mathrm{C}$, then $\mathrm{PPh}_{3}, 95 \%$. DIAD: diisopropylazodicarboxylate.

\section{Alkoxyallene-yne Pauson-Khand reactions}

With a range of alkoxyallene-ynes in hand, the feasibility of the Pauson-Khand cyclocarbonylation was next investigated. Mukai and co-workers, ${ }^{[23]}$ Brummond and co-workers, ${ }^{[24]}$ and, more recently, our group ${ }^{[25]}$ reported that the $\mathrm{Rh}^{\prime}$-catalyzed intramolecular allene-yne PKR was a very efficient tool for the construction of bicyclo[5.3.0] ring frameworks.

Therefore, a first examination of the PKR conditions was performed with 12 b ( $\left.R^{1}: O C b ; R^{2}: M e\right)$ and 13 a $\left(R^{1}: O B n ; R^{2}: M e\right)$ by using commercially available $\left[\mathrm{Rh}(\mathrm{Cl})(\mathrm{CO})_{2}\right]_{2}$ and $[\mathrm{Rh}(\operatorname{cod}) \mathrm{Cl}]_{2}$ (cod: cycloocta-1,5-diene) as catalysts.

When subjected to the conditions of Brummond and coworkers, that is, $10 \mathrm{~mol} \%$ of $\left[\mathrm{Rh}(\mathrm{Cl})(\mathrm{CO})_{2}\right]_{2}$ in toluene at $90^{\circ} \mathrm{C}$ under a carbon monoxide atmosphere, $12 \mathrm{~b}$ and $13 \mathrm{a}$ afforded 


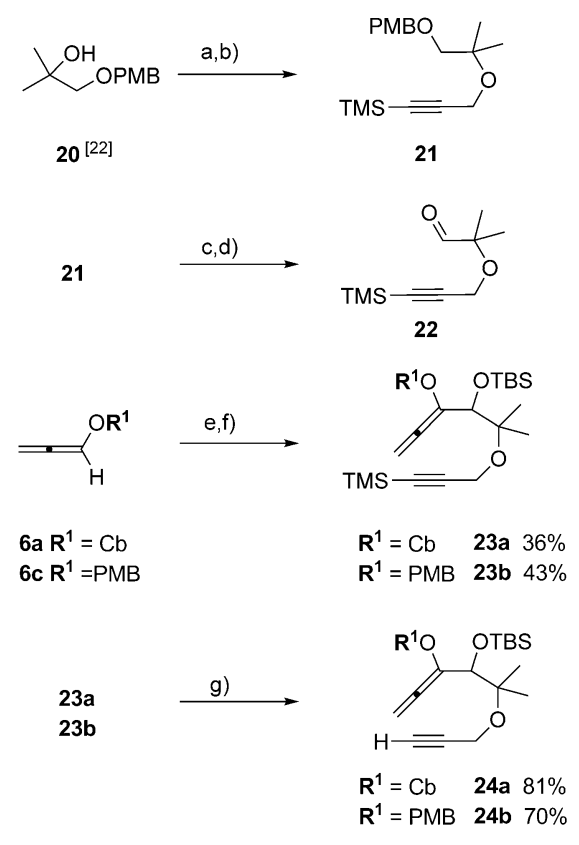

Scheme 8. Preparation of alkoxyallene-ynes in oxygen series. a) $\mathrm{NaH}$, propargyl bromide, $\mathrm{THF}, 0^{\circ} \mathrm{C}$ to RT, then reflux, $12 \mathrm{~h}, 95 \%$. b) $n \mathrm{BuLi}, \mathrm{TMSCl}, \mathrm{THF}$, $-78{ }^{\circ} \mathrm{C}, 45$ min, quant. c) $\mathrm{DDQ}, \mathrm{CH}_{2} \mathrm{Cl}_{2} / \mathrm{H}_{2} \mathrm{O}, 0^{\circ} \mathrm{C}$ to $\mathrm{RT}, 12 \mathrm{~h}, 87 \%$. d) $(\mathrm{COCl})_{2}$ DMSO, $\mathrm{Et}_{3} \mathrm{~N}, \mathrm{CH}_{2} \mathrm{Cl}_{2},-78^{\circ} \mathrm{C}$ to RT, $92 \%$. e) $n \mathrm{BuLi}, \mathrm{THF},-78^{\circ} \mathrm{C}, 30 \mathrm{~min}$, then aldehyde $22, \mathrm{THF},-78^{\circ} \mathrm{C}, 30 \mathrm{~min}$. f) TBSOTf, 2,6-lutidine, $\mathrm{CH}_{2} \mathrm{Cl}_{2}, 0^{\circ} \mathrm{C}, 3 \mathrm{~h}$. g) $\mathrm{K}_{2} \mathrm{CO}_{3}, \mathrm{MeOH}$. DDQ: 2,3-dichloro-5,6-dicyano-1,4-benzoquinone.

\begin{tabular}{|c|c|c|c|c|c|c|}
\hline & Catalyst/ligand & Solvent & $\begin{array}{l}T \\
{\left[{ }^{\circ} \mathrm{C}\right]}\end{array}$ & $\begin{array}{l}t \\
{[\mathrm{~h}]}\end{array}$ & $\begin{array}{l}\text { Conversion } \\
\text { [\%] }\end{array}$ & $\begin{array}{l}\text { Yield of } \\
25 b[\%]\end{array}$ \\
\hline 1 & {$\left[\mathrm{Rh}(\mathrm{Cl})(\mathrm{CO})_{2}\right]_{2} /-$} & toluene & 90 & 1.5 & 100 & 70 \\
\hline 2 & {$\left[\mathrm{Rh}(\mathrm{Cl})(\mathrm{CO})_{2}\right]_{2} /-$} & toluene & RT & 8 & 100 & 70 \\
\hline 3 & {$\left[\mathrm{Rh}(\mathrm{Cl})(\mathrm{CO})_{2}\right]_{2} /-$} & THF & 110 & 2 & 100 & 70 \\
\hline 4 & {$\left[\mathrm{Rh}(\mathrm{Cl})(\mathrm{CO})_{2}\right]_{2} / \mathrm{dpp}^{[\mathrm{a}]}$} & toluene & 110 & 3 & 100 & 88 \\
\hline 5 & {$\left[\mathrm{Rh}(\mathrm{Cl})(\mathrm{CO})_{2}\right]_{2} / \mathrm{dppp}$} & acetonitrile & 110 & 20 & 0 & - \\
\hline 6 & {$\left[\mathrm{Rh}(\mathrm{Cl})(\mathrm{CO})_{2}\right]_{2} / \mathrm{dppp}$} & THF & 110 & 20 & 0 & - \\
\hline 7 & {$[\mathrm{Rh}(\operatorname{cod}) \mathrm{Cl}]_{2} / \mathrm{dppp}$} & toluene & 110 & 20 & 100 & quant. \\
\hline 8 & {$[\mathrm{Rh}(\operatorname{cod}) \mathrm{Cl}]_{2} / \mathrm{dppp}$} & THF & 110 & 20 & 0 & - \\
\hline
\end{tabular}

portant yield enhancement, especially in the benzyl series, for which the yield of 26 a rose from 38 to $77 \%$. Thus, although the reaction time was lengthened, fewer byproducts were generated in the course of the reaction.

Finally, replacement of the $\mathrm{Rh}^{\prime}$ catalyst $\left[\mathrm{Rh}(\mathrm{Cl})(\mathrm{CO})_{2}\right]_{2}$ with $[\mathrm{Rh}(\operatorname{cod}) \mathrm{Cl}]_{2}$, always in the presence of $50 \mathrm{~mol} \%$ of dppp (the conditions of Mukai and co-workers), ${ }^{[23]}$ brought about significant improvement in the PKR and resulted in the formation of $\mathbf{2 5}$ b in quantitative yield ( $\mathrm{Cb}$ series; Table 1, entry 7) and 26 a in $90 \%$ yield (Bn series; Table 2, entry 8 ). These results suggest that the nature of the catalyst appears to be an underlying factor of the reaction. ${ }^{[14,26]}$

Our study then focused on the influence of solvent and ligand nature on the reaction. Replacement of toluene by THF or acetonitrile did not improve the results, with the catalyst complex being insoluble in these solvents (Table 1, entries 5, 6, and 8 ; Table 2, entry 3 ). If a cationic rhodium complex was used, that is, $\left[\mathrm{Rh}(\mathrm{Cl})(\mathrm{CO})_{2}\right]_{2} / \mathrm{dppp}$ or $[\mathrm{Rh}(\operatorname{cod}) \mathrm{Cl}]_{2} / \mathrm{dppp}$ in the presence of AgOTf, inconclusive results were observed with substrate 13a ( $R^{1}$ : OBn; Table 2, entries 7 and 9). ${ }^{[27]}$ In the benzyl series, the reaction was next explored in the presence of various phosphorus ligands (phosphines, hydroxyphosphines, or phosphites: Xantphos, $\mathrm{PO}$, and $\left.\mathrm{P}(\mathrm{OEt})_{3}\right)$ but with inconclusive outcomes (Table 2 , entries 5,6 , and 10). ${ }^{[28]}$

It should be noted that bicyclic $[5,6]$ products resulting from the PKR between the vicinal double bond of the alkoxy-allene and the alkyne function have never been observed.

With the feasibility of the alkoxyallene-yne Pauson-Khand cyclocarbonylation established and the optimized reaction conditions in hand (that is, $[\mathrm{Rh}(\mathrm{cod}) \mathrm{Cl}]_{2}(10 \mathrm{~mol} \%)$ modified with dppp (50 mol\%), in toluene heated to reflux under $1 \mathrm{~atm}$ of $(\mathrm{O})$, we set out to explore the scope of this reaction for the preparation of a number of perhydroazulene systems. Interestingly, in the carbamate and benzyl series $\left(R^{1}: C b\right.$ or $\left.B n\right)$, the treatment of alkynes $12 \mathrm{a}, 12 \mathrm{c}-\mathrm{e}$, and $13 \mathrm{~b}\left(\mathrm{R}^{2}: \mathrm{H}, \mathrm{Et}, \mathrm{TMS}\right.$, or $\mathrm{CH}_{2} \mathrm{OBn}$ ) under optimal conditions provided the unsaturated bicyclo[5.3.0] ring systems $25 \mathrm{a}, 25 \mathrm{c}-\mathbf{e}$, and $26 \mathrm{~b}$ in similar yields, which illustrates the high tolerance of this cycloaddition reaction (Scheme 9 and Scheme 10). Moreover, extension of the repertoire of allenes to the PMB series $\left(R^{1}\right.$ : $\left.P M B\right)$ also per- the desired products $\mathbf{2 5} \mathrm{b}$ and $\mathbf{2 6} \mathrm{a}$ with full conversion within $1.5 \mathrm{~h}$. Notably, $25 \mathrm{~b}$ was isolated in good yield (70\%; Table 1, entry 1$)$, whereas 26 a was obtained in moderate yield (38\%), along with byproducts, which indicated stability problems (Table 2, entry 1). If the temperature was lowered to $25^{\circ} \mathrm{C}$, the reaction of $12 \mathrm{~b}$ ( $\mathrm{Cb}$ series) interestingly reached completion in $8 \mathrm{~h}$ (Table 1, entry 2), whereas only $10 \%$ conversion was observed after $20 \mathrm{~h}$ in the benzyl series (Table 2, entry 2). Alternatively, if the reaction was performed in THF, there was no improvement whatever in the series (Tables 1 and 2, entry 3).

Exposure to $10 \mathrm{~mol} \%$ of $\left[\mathrm{Rh}(\mathrm{Cl})(\mathrm{CO})_{2}\right]_{2}$ modified with dppp $(50 \mathrm{~mol} \%)$ in toluene heated to reflux under CO (1 atm; Table 1 and 2, entry 4) led to an im-
Table 2. Optimization of the alkoxyallene-yne Pauson-Khand reaction with 13 a $\left(R^{1}\right.$ : $\left.\mathrm{Bn} ; \mathrm{R}^{2}: \mathrm{Me}\right)$.

\begin{tabular}{|c|c|c|c|c|c|c|}
\hline & Catalyst/ligand & Solvent & $\begin{array}{l}T \\
{\left[{ }^{\circ} \mathrm{C}\right]}\end{array}$ & $\begin{array}{l}t \\
{[\mathrm{~h}]}\end{array}$ & $\begin{array}{l}\text { Conversion } \\
{[\%]}\end{array}$ & $\begin{array}{l}\text { Yield of } \\
26 \text { a [\%] }\end{array}$ \\
\hline 1 & {$\left[\mathrm{Rh}(\mathrm{Cl})(\mathrm{CO})_{2}\right]_{2} /-$} & toluene & 90 & 1.5 & 100 & 38 \\
\hline 2 & {$\left[\mathrm{Rh}(\mathrm{Cl})(\mathrm{CO})_{2}\right]_{2} /-$} & toluene & RT & 20 & 10 & - \\
\hline 3 & {$\left[\mathrm{Rh}(\mathrm{Cl})(\mathrm{CO})_{2}\right]_{2} /-$} & THF & 110 & 2 & 100 & 20 \\
\hline 4 & {$\left[\mathrm{Rh}(\mathrm{Cl})(\mathrm{CO})_{2}\right]_{2} / \mathrm{dppp}$} & toluene & 110 & 6 & 100 & 77 \\
\hline 5 & {$\left[\mathrm{Rh}(\mathrm{Cl})(\mathrm{CO})_{2}\right]_{2} / \mathrm{P}(\mathrm{OEt})_{3}$} & acetonitrile & 110 & 4 & 100 & 24 \\
\hline 6 & {$\left[\mathrm{Rh}(\mathrm{Cl})(\mathrm{CO})_{2}\right]_{2} / \mathrm{PO}^{[\mathrm{a}]}$} & THF & 110 & 4 & 100 & 52 \\
\hline 7 & {$\left[\mathrm{Rh}(\mathrm{Cl})(\mathrm{CO})_{2}\right]_{2} / \mathrm{dppp}, \mathrm{AgOTf}$} & toluene & 110 & 1.5 & 20 & - \\
\hline 8 & {$[\mathrm{Rh}(\operatorname{cod}) \mathrm{Cl}]_{2} / \mathrm{dppp}$} & toluene & 110 & 28 & 100 & 90 \\
\hline 9 & {$[\mathrm{Rh}(\operatorname{cod}) \mathrm{Cl}]_{2} / \mathrm{dppp}, \mathrm{AgOTf}$} & toluene & 110 & 20 & 0 & - \\
\hline 10 & {$[\mathrm{Rh}(\operatorname{cod}) \mathrm{Cl}]_{2} /$ Xantphos } & THF & 110 & 20 & 0 & - \\
\hline
\end{tabular}




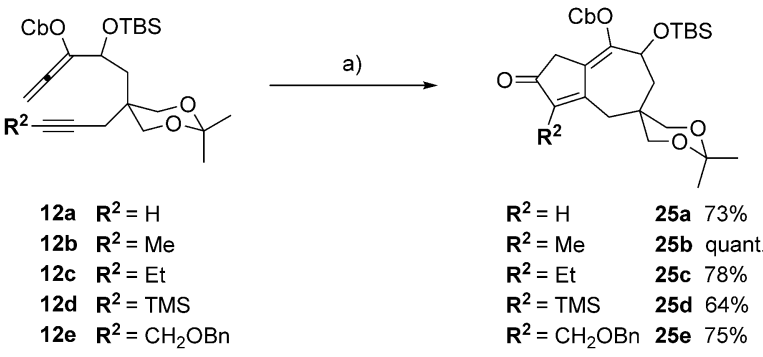

Scheme 9. Alkoxyallene-yne Pauson-Khand cyclocarbonylations with the all-carbon series ( $\left.\mathrm{R}^{1}: \mathrm{Cb}\right)$. a) $[\mathrm{Rh}(\mathrm{cod}) \mathrm{Cl}]_{2}(10 \mathrm{~mol} \%)$, dppp (50 mol\%), $\mathrm{CO}$ (1 atm), toluene, $110^{\circ} \mathrm{C},[\mathrm{c}]=0.1 \mathrm{M}$.
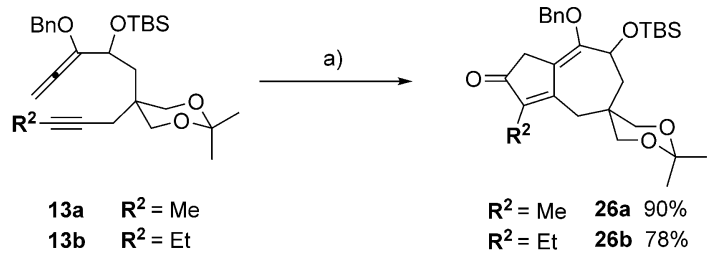

Scheme 10. Alkoxyallene-yne Pauson-Khand cyclocarbonylations with the all-carbon series $\left(\mathrm{R}^{1}: \mathrm{Bn}\right)$. a) $[\mathrm{Rh}(\mathrm{cod}) \mathrm{Cl}]_{2}(10 \mathrm{~mol} \%)$, dppp (50 mol\%), CO (1 atm), toluene, $110^{\circ} \mathrm{C},[\mathrm{C}]=0.1 \mathrm{M}$.
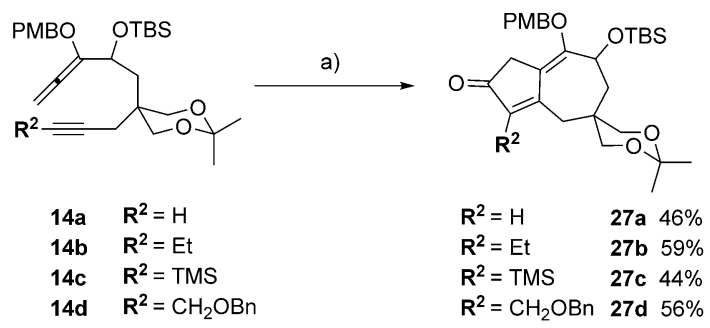

Scheme 11. Alkoxyallene-yne Pauson-Khand cyclocarbonylations with the all-carbon series ( $\mathrm{R}^{1}$ : PMB). a) $\left[\mathrm{Rh}(\mathrm{cod}) \mathrm{Cl}_{2}\right.$ (10 mol\%), dppp (50 mol\%), CO (1 atm), toluene, $110^{\circ} \mathrm{C},[\mathrm{C}]=0.1 \mathrm{M}$.

mitted the preparation of dienones $27 \mathrm{a}-\mathbf{d}\left(\mathrm{R}^{2}: \mathrm{H}, \mathrm{Et}, \mathrm{TMS}\right.$, and $\mathrm{CH}_{2} \mathrm{OBn}$ ) in $44-59 \%$ yields from $14 \mathrm{a}-\mathbf{d}$ (Scheme 11 ).

Our next task focused on the application of the optimal $\mathrm{Rh}^{\prime}$-catalyzed PKR conditions to the construction of aza- and oxabicyclo[5.3.0] ring systems.

In contrast to all-carbon alkoxyallene-ynes, the cyclocarbonylation reaction with nitrogen-tether compounds $16 \mathrm{a}-\mathrm{c}, 17 \mathrm{a}-\mathrm{c}$, and $18 \mathrm{a}-\mathbf{d}\left(\mathrm{R}^{1}: \mathrm{Cb}, \mathrm{Bn}\right.$, and $\mathrm{PMB} ; \mathrm{R}^{2}: \mathrm{H}, \mathrm{Et}, \mathrm{TMS}$, and $\left.\mathrm{CH}_{2} \mathrm{OBn}\right)$ appeared more challenging (Scheme 12). Hence, under the previously developed conditions, the reaction led to the desired bicyclic systems $28 \mathrm{a}-\mathrm{c}, 29 \mathrm{a}-\mathrm{c}, 30 \mathrm{a}$, and $30 \mathrm{~b}$ in moderate yields ranging from 21 to $59 \%$ and to an intractable mixture for $30 \mathrm{c}$ and $\mathbf{3 0 d}$ (the target compound could never be separated from the byproducts). The best results were attained in the carbamate series, whereas lower yields were observed in the PMB series. Unidentifiable products were systematically obtained along with dienones, which provided evidence that

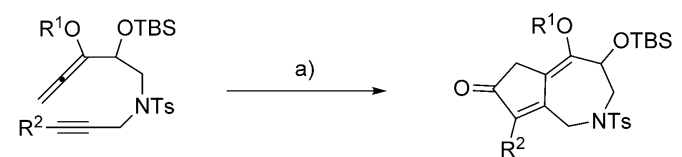

\begin{tabular}{|c|c|c|c|c|c|}
\hline $\begin{array}{l}16 a \\
16 b \\
16 c\end{array}$ & $\mathbf{R}^{1}=\mathrm{Cb}$ & $\begin{array}{l}\mathbf{R}^{2}=\mathrm{H} \\
\mathbf{R}^{2}=\mathrm{TMS} \\
\mathbf{R}^{2}=\mathrm{CH}_{2} \mathrm{OBn}\end{array}$ & $\mathbf{R}^{1}=\mathrm{Cb}$ & $\begin{array}{l}\mathbf{R}^{2}=\mathrm{H} \\
\mathbf{R}^{2}=\mathrm{TMS} \\
\mathbf{R}^{2}=\mathrm{CH}_{2} \mathrm{OBn}\end{array}$ & $\begin{array}{l}28 \mathrm{a} \\
28 \mathrm{~b} \\
28 \mathrm{c}\end{array}$ \\
\hline $\begin{array}{l}17 a \\
17 b \\
17 c\end{array}$ & $\mathbf{R}^{1}=\mathrm{Bn}$ & $\begin{array}{l}\mathbf{R}^{2}=\mathrm{H} \\
\mathbf{R}^{2}=\mathrm{Et} \\
\mathbf{R}^{2}=\mathrm{CH}_{2} \mathrm{OBn}\end{array}$ & $\mathbf{R}^{1}=\mathrm{Bn}$ & $\begin{array}{l}\mathbf{R}^{2}=\mathrm{H} \\
\mathbf{R}^{2}=\mathrm{Et} \\
\mathbf{R}^{2}=\mathrm{CH}_{2} \mathrm{OBn}\end{array}$ & $\begin{array}{l}29 a \\
29 b \\
29 c\end{array}$ \\
\hline $\begin{array}{l}18 a \\
18 b \\
18 c \\
18 d\end{array}$ & $\mathbf{R}^{1}=\mathrm{PMB}$ & $\begin{array}{l}\mathbf{R}^{2}=\mathrm{H} \\
\mathbf{R}^{2}=\mathrm{Et} \\
\mathbf{R}^{2}=\mathrm{TMS} \\
\mathbf{R}^{2}=\mathrm{CH}_{2} \mathrm{OBn}\end{array}$ & $\mathrm{R}^{1}=\mathrm{PMB}$ & $\begin{array}{l}\mathbf{R}^{2}=\mathrm{H} \\
\mathbf{R}^{2}=\mathrm{Et} \\
\mathbf{R}^{2}=\mathrm{TMS} \\
\mathbf{R}^{2}=\mathrm{CH}_{2} \mathrm{OBn}\end{array}$ & $\begin{array}{l}30 a \\
30 b \\
30 c \\
30 d\end{array}$ \\
\hline
\end{tabular}

Scheme 12. Synthesis of azabicyclo[5.3.0] ring systems through alkoxyalleneyne Pauson-Khand reactions. a) $\left[\mathrm{Rh}(\mathrm{cod}) \mathrm{Cl}_{2}(10 \mathrm{~mol} \%), \mathrm{dppp}(50 \mathrm{~mol} \%), \mathrm{CO}\right.$ (1 atm), toluene, $110^{\circ} \mathrm{C},[c]=0.1 \mathrm{M}$.

either the starting material or the product is unstable under the reactions conditions.

Finally, similar results were observed in the oxygen-tethered series, for which the yields of the bicyclic [5,7] products $31 \mathrm{a}$, $31 \mathrm{~b}, 32 \mathrm{a}$, and $\mathbf{3 2} \mathbf{b}$ varied from moderate to low (Scheme 13). In some instances, complete decomposition of the substrate occurred, particularly in the PMB series ( $\mathrm{R}^{2}$ : TMS).

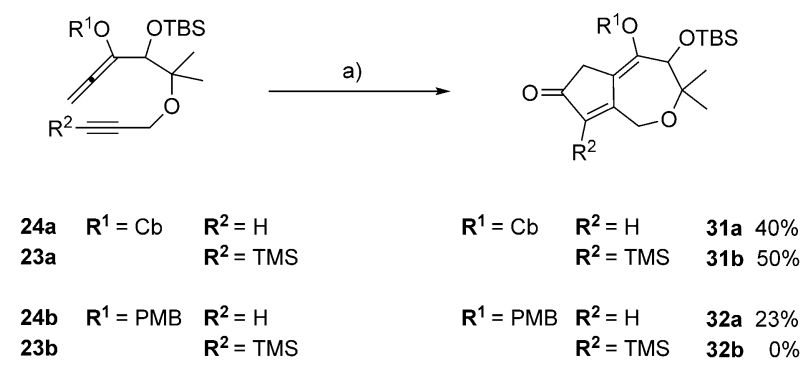

Scheme 13. Synthesis of oxabicyclo[5.3.0] ring systems through alkoxyallene-yne Pauson-Khand reactions. a) $[\mathrm{Rh}(\operatorname{cod}) \mathrm{Cl}]_{2}(10 \mathrm{~mol} \%)$, dppp (50 mol\%), $\mathrm{CO}(1 \mathrm{~atm})$, toluene, $110^{\circ} \mathrm{C},[\mathrm{c}]=0.1 \mathrm{M}$.

Thus, we have clearly established the scope of the alkoxyallene-yne Pauson-Khand reaction from alkoxyallenes bearing alkoxy groups at the proximal position. Alkoxyallene-ynes presenting various substitution patterns at the allenol and the alkyne moiety, as well as three different tethers (carbon, nitrogen, and oxygen series), have been submitted to optimized PKR conditions $\left([\mathrm{Rh}(\operatorname{cod}) \mathrm{Cl}]_{2} / \mathrm{dppp}\right)$. The ring-closing reaction has been found to occur exclusively between the distal double bond of the alkoxyallene moiety and the alkyne counterpart, which results in the formation of homo- or heterobicyclo[5.3.0]decadienone frameworks. Notably, the best results were obtained in the carbamate series, whatever the tether $(C$, $\mathrm{N}$, or $\mathrm{O}$ ), which provides evidence for the importance of the electronic effect of the carbamate on the stability of both the starting alkoxyallene and the resulting enol. Moreover, a strong 
substituent effect has been observed at the alkyne moiety, for which a TMS group systematically led to a substantial drop in yield. Finally, among the three elected tethers, the most promising results were observed in the carbon series. Although one cannot fully exclude the influence of heteroatoms, the most plausible explanation is the stronger Thorpe-Ingold effect in the carbon series than in the heteroatom series (Scheme 14).

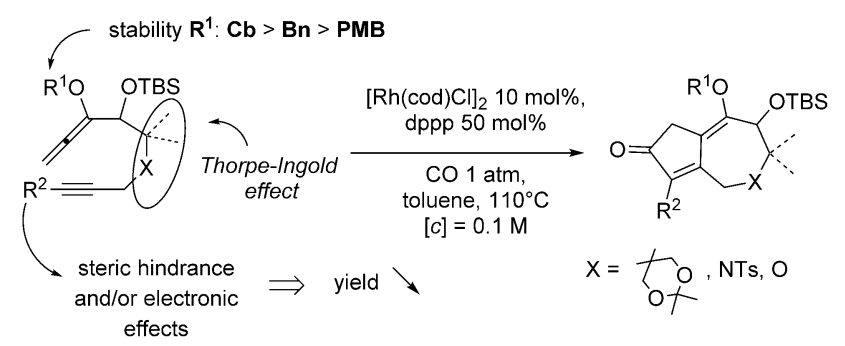

Scheme 14. Factors influencing the synthesis of bicyclo[5.3.0] ring systems through alkoxyallene-yne Pauson-Khand reactions.

Finally, the success of the alkoxyallene-yne PKR in the carbamate series prompted us to examine the cleavage of this enol ether. Thereby, in a first trial, the reaction of $\mathrm{Cb}$ ether $\mathbf{3 1} \mathbf{b}$ with excess trimethylsilyl trifluoromethanesulfonate (TMSOTf) ${ }^{[29]}$ provided ketone $( \pm)$-33 as only one diastereomer, which thus demonstrates the synthetic utility of this cyclocarbonylation reaction for accessing tertiary-alcohol-containing guaiane systems (Scheme 15).

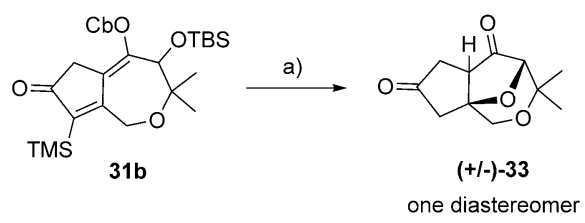

Scheme 15 . Cleavage of the carbamate enol ether moiety of $\mathbf{3 1} \mathbf{b}$. a) TMSOTf (excess), toluene, $-78^{\circ} \mathrm{C}$, then $\mathrm{H}_{2} \mathrm{O}, 20 \%$, only one diastereomer observed in NMR spectra (not optimized).

\section{Conclusion}

We have successfully performed intramolecular rhodiumcatalyzed Pauson-Khand cyclocarbonylation reactions of alkoxyallene-ynes with the alkoxy group at the proximal position to access [5,7] ring systems bearing an enol ether. These reactions can be applied to the selective construction of allcarbon-containing bicyclo[5.3.0]decadienones, as well as azaand oxabicyclo[5.3.0]decadienones. This study clearly establishes the versatility and tolerance of this reaction to a variety of useful functional groups present in the alkoxyallene-yne substrates. Moreover, cleavage of the carbamate enol ether was also accomplished, which demonstrates that this cyclocarbonylation reaction may become a method of choice as an access to the carbon framework of guaianes possessing a tertiary hydroxy group at the $\mathrm{C} 10$ position. The application of this
Pauson-Khand reaction to the total synthesis of thapsigargin is now in progress.

\section{Experimental Section}

Typical procedure for the PKR: A microwave vial equipped with a Teflon-coated stirrer bar and a septum cap was charged with allene-yne and freshly distilled toluene $(0.1 \mathrm{M})$. The solution was degassed by bubbling with argon for $5 \mathrm{~min}$, then a $\mathrm{CO}$ atmosphere was installed. Dppp (0.50 equiv) and $\left[\mathrm{Rh}(\mathrm{CO})_{2} \mathrm{Cl}\right]_{2}$ ( 0.10 equiv; or $\left.[\mathrm{Rh}(\mathrm{cod}) \mathrm{Cl}]_{2}\right)$ were successively added in one portion, and the mixture was submitted to bubbling $\mathrm{CO}$ for $2 \mathrm{~min}$. The reaction vial was placed in a preheated $110^{\circ} \mathrm{C}$ oil bath and stirred under a $\mathrm{CO}$ atmosphere. The reaction was monitored by TLC. Upon completion, the mixture was cooled to room temperature and concentrated under reduced pressure. The resulting residue was purified by flash chromatography on silica gel.

\section{Acknowledgements}

We thank ANR for doctoral fellowships for A.T. and M.J. and an assistant engineer fellowship for M.A.

Keywords: allenes · alkynes · cyclization - Pauson-Khand reactions - rhodium

[1] a) For a review on guaianolides, see: A. Schall, O. Reiser, Eur. J. Org. Chem. 2008, 2353-2364; b) Pogostol: Y. Yang, K. Kinoshita, K. Koyama, K. Takahashi, T. Tai, Y. Nunoura, K. Watanabe, Phytomedicine 1999, 6, 89-93; c) Arglabin: S. M. Adekenov, M. N. Mukhametzhanov, A. D. Kagarlitskii, A. N. Kupriyanov, Khim. Prir. Soedin. 1982, 5, 655-656; d) Chinensiolide: S. Zhang, J. Wang, H. Xue, Q. Deng, F. Xing, M. Ando, J. Nat. Prod. 2002, 65, 1927-1929; e) Thapsigargin: U. S. B. Rasmussen, S. B. Christensen, F. Sandberg, Acta Pharm. Suec. 1978, 15, 133-140; f) Artabsin: K. Vokac, Z. Samek, V. Herout, F. Sorm, Tetrahedron Lett. 1968, 9, 3855 -3857; g) Ledol: V. Z. Pletnev, I. N. Tsygannik, Y. D. Fonarev, I. Y. Mikhailova, A. I. Miroshnikov, Bioorg. Khim. 1993, 19, 366-372; h) Englerin A: R. Ratnayake, D. Covell, T. T. Ransom, K. R. Gustafson, J. A. Beutler, Org. Lett. 2009, 11, 57-60.

[2] a) I. U. Khand, G. R. Knox, P. L. Pauson, W. E. Watts, M. I. Foreman, J. Chem. Soc. Perkin Trans. 1 1973, 977-981. For a recent book on Pauson-Khand type reactions, see: b) R. R. Torres, The Pauson-Khand Reaction: Scope, Variations and Applications, Wiley, Chichester, 2012. For reviews, see: c) K. M. Brummond, J. L. Kent, Tetrahedron 2000, 56, 3263 3283; d) B. Alcaide, P. Almendros, Eur. J. Org. Chem. 2004, 3377-3383; e) J. Blanco-Urgoiti, L. Anorbe, L. Perez-Serrano, G. Dominguez, J. PerezCastells, Chem. Soc. Rev. 2004, 33, $32-42$; f) S. Kitagaki, F. Inagaki, C. Mukai, Chem. Soc. Rev. 2014, 43, 2956-2978.

[3] For a recent review on alkoxyallenes, see: R. Zimmer, H.-U. Reissig, Chem. Soc. Rev. 2014, 43, 2888-2903.

[4] J. Castro, A. Moyano, M. A. Pericas, A. Riera, A. E. Greene, A. AlvarezLarena, J. F. Piniella, J. Org. Chem. 1996, 61, 9016-9020.

[5] M. Ahmar, O. Chabanis, J. Gauthier, B. Cazes, Tetrahedron Lett. 1997, 38, 5277-5280.

[6] Á. González-Gómez, L. Añorbe, A. Poblador, G. Domínguez, J. Pérez-Castells, Eur. J. Org. Chem. 2008, 1370-1377.

[7] K. M. Brummond, M. M. Davis, C. Huang, J. Org. Chem. 2009, 74, 8314 8320.

[8] B. M. Trost, J. Xie, J. Am. Chem. Soc. 2006, 128, 6044-6045.

[9] O. Flögel, H.-U. Reißig, Eur. J. Org. Chem. 2004, 2797-2804.

[10] D. Hoppe, C. Gonschorrer, D. Schmidt, E. Egert, Tetrahedron 1987, 43, $2457-2466$.

[11] In these reactions, complete conversion has never been achieved, despite heating of the mixture to $60^{\circ} \mathrm{C}$ or addition of one equivalent of base. 
[12] I. Ojima, A. T. Vu, S.-Y. Lee, J. V. McCullagh, A. C. Moralee, M. Fujiwara, T. H. Hoang, J. Am. Chem. Soc. 2002, 124, 9164-9174.

[13] H. Chakrapani, C. Liu, R. A. Widenhoefer, Org. Lett. 2003, 5, 157-159.

[14] T. Kobayashi, Y. Koga, K. Narasaka, J. Organomet. Chem. 2001, 624, $73-$ 87.

[15] P. Wipf, L. T. Rahman, S. R. Rector, J. Org. Chem. 1998, 63, 7132-7133.

[16] Given their relative instability, the resulting alcohols have been directly protected as silyl ethers.

[17] a) J. Cui, J. Hao, O. A. Ulanovskaya, J. Dundas, J. Liang, S. A. Kozmin Proc. Natl. Acad. Sci. USA 2011, 108, 6763-6768; b) H. Song, Y. Liu, Q. Wang, Org. Lett. 2013, 15, 3274-3277.

[18] a) K. Masuda, N. Sakiyama, R. Tanaka, K. Noguchi, K. Tanaka, J. Am. Chem. Soc. 2011, 133, 6918-6921; b) D. A. Candito, M. Lautens, Synlett 2011, 1987-1992.

[19] K. Shen, X. Han, X. Lu, Org. Lett. 2013, 15, 1732-1735.

[20] B. L. Ashfeld, S. F. Martin, Tetrahedron 2006, 62, 10497-10506.

[21] S. M. Kim, J. H. Park, S. Y. Choi, Y. K. Chung, Angew. Chem. Int. Ed. 2007 46, 6172-6175; Angew. Chem. 2007, 119, 6284-6287.

[22] A. Commerçon, J.-D. Bourzat, D. Bézard, M. Vuilhorgne, Tetrahedron 1994, 50, 10289-10298.

[23] a) C. Mukai, T. Hirose, S. Teramoto, S. Kitagaki, Tetrahedron 2005, 61, $10983-10994$; b) T. Hirose, N. Miyakoshi, C. Mukai, J. Org. Chem. 2008,
73, $1061-1066$; c) C. Mukai, I. Nomura, K. Yamanishi, M. Hanaoka, Org. Lett. 2002, 4, 1755-1758.

[24] a) A. S. Bayden, K. M. Brummond, K. D. Jordan, Organometallics 2006 25, 5204-5206; b) F. Grillet, C. Huang, K. M. Brummond, Org. Lett. 2011 13,6304-6307; c) F. Grillet, K. M. Brummond, J. Org. Chem. 2013, 78, $3737-3754$.

[25] A. Tap, M. Jouanneau, G. Galvani, G. Sorin, M.-I. Lannou, J.-P. Férézou, J. Ardisson, Org. Biomol. Chem. 2012, 10, 8140-8146.

[26] a) A. R. Sanger, J. Chem. Soc. Dalton Trans. 1977, 120-129; b) H. Wang, J. R. Sawyer, P. A. Evans, M.-H. Baik, Angew. Chem. Int. Ed. 2008, 47, $342-$ 345; Angew. Chem. 2007, 119, 348-351.

[27] a) P. A. Wender, N. M. Deschamps, G. G. Gamber, Angew. Chem. Int. Ed. 2003, 42, 1853-1857; Angew. Chem. 2003, 115, 1897-1901; b) N Jeong, Organometallics 1998, 17, 3642-3644; c) D. E. Kim, V. Ratovelomanana-Vidal, N. Jeonga, Adv. Synth. Catal. 2010, 352, $2032-2040$.

[28] Hydroxyphosphine ligand PO: N. Yoshikai, H. Matsuda, E. Nakamura, J. Am. Chem. Soc. 2009, 131, 9590-9599.

[29] M. Seppi, R. Kalkofen, J. Reupohl, R. Fröhlich, D. Hoppe, Angew. Chem. Int. Ed. 2004, 43, 1423-1427; Angew. Chem. 2004, 116, 1447-1451. 